\title{
The rates of major malformations after gestational exposure to isotretinoin: a systematic review and meta-analysis
}

\author{
Eun Jeong Choi, MD, PhD ${ }^{1,2}$, NaeRy Kim, MD, PhD ${ }^{1,3}$, Ho-Seok Kwak, MS¹, Hae Ji Han, RN, MS ${ }^{1}$,
} Kyoung-Chul Chun, MD, PhD², Young-Ah Kim MD, PhD2 , Jae-Whoan Koh, MD, PhD², Jung Yeol Han, MD, PhD ${ }^{1,2}$, Sung Hong Joo, MD, PhD ${ }^{1,4}$, Ji Sung Lee, MD, PhD ${ }^{5}$, Gideon Koren, MD, PhD ${ }^{6}$

\begin{abstract}
${ }^{1}$ Korean Mothersafe Counselling Center, Pregnancy \& Breastfeeding Medicines Information Center, Seoul; ${ }^{2}$ Department of Obstetrics and Gynecology, Inje University Ilsan Paik Hospital, Goyang; ${ }^{3}$ Department of Obstetrics and Gynecology, Konkuk University Medical Center, Konkuk University School of Medicine, ${ }^{4}$ Department of Obstetrics and Gynecology, National Medical Center, ${ }^{5}$ Clinical Research Center, Asan Institute for Life Sciences, Asan Medical Center, University of Ulsan College of Medicine, Seoul, Korea; ${ }^{6}$ Motherisk Israel and Adelson faculty of Medicine, Ariel University, Ariel, Israel
\end{abstract}

\section{Objective}

Isotretinoin is among the most notorious human teratogens, documented originally as causing up to $30 \%$ of malformations. This systematic review and meta-analysis aimed to evaluate the rates of major malformation (MM) among isotretinoin-exposed pregnant women over the years through a systematic review and meta-analysis.

\section{Methods}

Eligible studies were searched and identified using various databases. Single-arm meta-analysis and meta-analysis of odd ratios among controlled studies were performed using Review Manager version 5.3.

\section{Results}

Ten eligible studies that combined 2,783 isotretinoin-exposed women were included in our study. The rate of MM weighted for the sample size was $15 \%$. Three studies that included an unexposed comparison group were eligible for the meta-analysis. The pooled odds ratio of MM for isotretinoin-exposed women was 3.76. After 2006, the pooled odds ratio of MM for isotretinoin exposure was significantly lower at 1.04.

\section{Conclusion}

The current rate of MM in isotretinoin-exposed women was substantially lower after 2006.

Keywords: Isotretinoin; Congenital malformations; Pregnancy; Meta-analysis; Systematic review

\section{Introduction}

Isotretinoin (13-cis-retinoic acid) was approved by the United States Food and Drug Administration for cystic, recalcitrant acne in 1982 [1]. As the most notorious teratogen since thalidomide, isotretinoin has been shown to adversely affect the development of the brain, face, palate, heart, spinal cord, ear, and thymus [2]. The causality of isotretinoin has been shown in both animal and human studies, and there is a recognizable pattern involving the cranial face, heart, thymus, and brain. It has been estimated to be caused by a common teratogenic mechanism, such as an inhibitory effect on normal activity and the interactive influence of neural
Received: 2020.11.29. Revised: 2021.01.03. Accepted: 2021.03.11. Corresponding author: Jung Yeol Han, MD, PhD

Department of Obstetrics and Gynaecology, Inje University Ilsan Paik Hospital, 170 Juhwa-ro, Ilsanseo-gu, Goyang 10380, Korea E-mail: hanjungyeol055@gmail.com https://orcid.org/0000-0001-5611-2392

Articles published in Obstet Gynecol Sci are open-access, distributed under the terms of the Creative Commons Attribution Non-Commercial License (http://creativecommons. org/licenses/by-nc/3.0/) which permits unrestricted non-commercial use, distribution, and reproduction in any medium, provided the original work is properly cited.

Copyright $\odot 2021$ Korean Society of Obstetrics and Gynecology 


\section{Obstetrics \& Gynecology Science}

Eun Jeong Choi, et al. Isotretinoin malformations: meta-analysis

crest cells [3]. The teratogenic mechanism of isotretinoin on neural crest cells is caused by changes in cytosolic calcium, bleb formation, and cell death in neural crest cells treated with isotretinoin and 4-oxo-isotretinoin [4].

The rate of major malformation (MM) was originally reported to be approximately $30 \%$ [3], and isotretinoin-exposed fetuses exhibited $30 \%$ mental retardation even in the absence of gross malformations and up to $60 \%$ poor performance in neuropsychological tests [5]. There are several limitations in estimating the accurate figure of teratogenic risk of isotretinoin, including various rates of MMs among published studies, and no accurate dose- and gestational age dependence. Additionally, while the elimination of the half-lives of isotretinoin and its active metabolite, 4-oxo-isotretinoin, have been reported at 29 and 22 hours, respectively, in extreme cases, the half-lives can be as long as a week [6].

There is some evidence that there is a lower occurrence of MM after exposure to lower dosages $[7,8]$. Importantly, the introduction of active pregnancy prevention programs for isotretinoin after 2005 probably resulted in lower rates of fetal exposure to the drug and higher rates of artificial abortion if exposure has occurred [9-11]. The aim of the present study was to update the estimates of the total rates and odds ratios (ORs) of MMs by a systematic review and meta-analysis based on all published data.

\section{Materials and methods}

\section{Search strategy}

Two reviewers (E.J.C and N.R.K) independently screened the references by titles and abstracts, followed by full-text assessment. Studies were selected for the meta-analysis based on the following inclusion criteria: 1) cross-sectional or cohort studies; 2) women exposed to isotretinoin during the periconception or pregnancy periods; 3) the study reported all adverse pregnancy outcomes; and 4) the study reported all birth outcomes, including malformations. In case of disagreement among reviewers during the selection process, a third reviewer served as a tie breaker (H.S.K and H.J.H). Reviews, animal studies, letters to the editor, and case reports as articles without full English text were excluded.

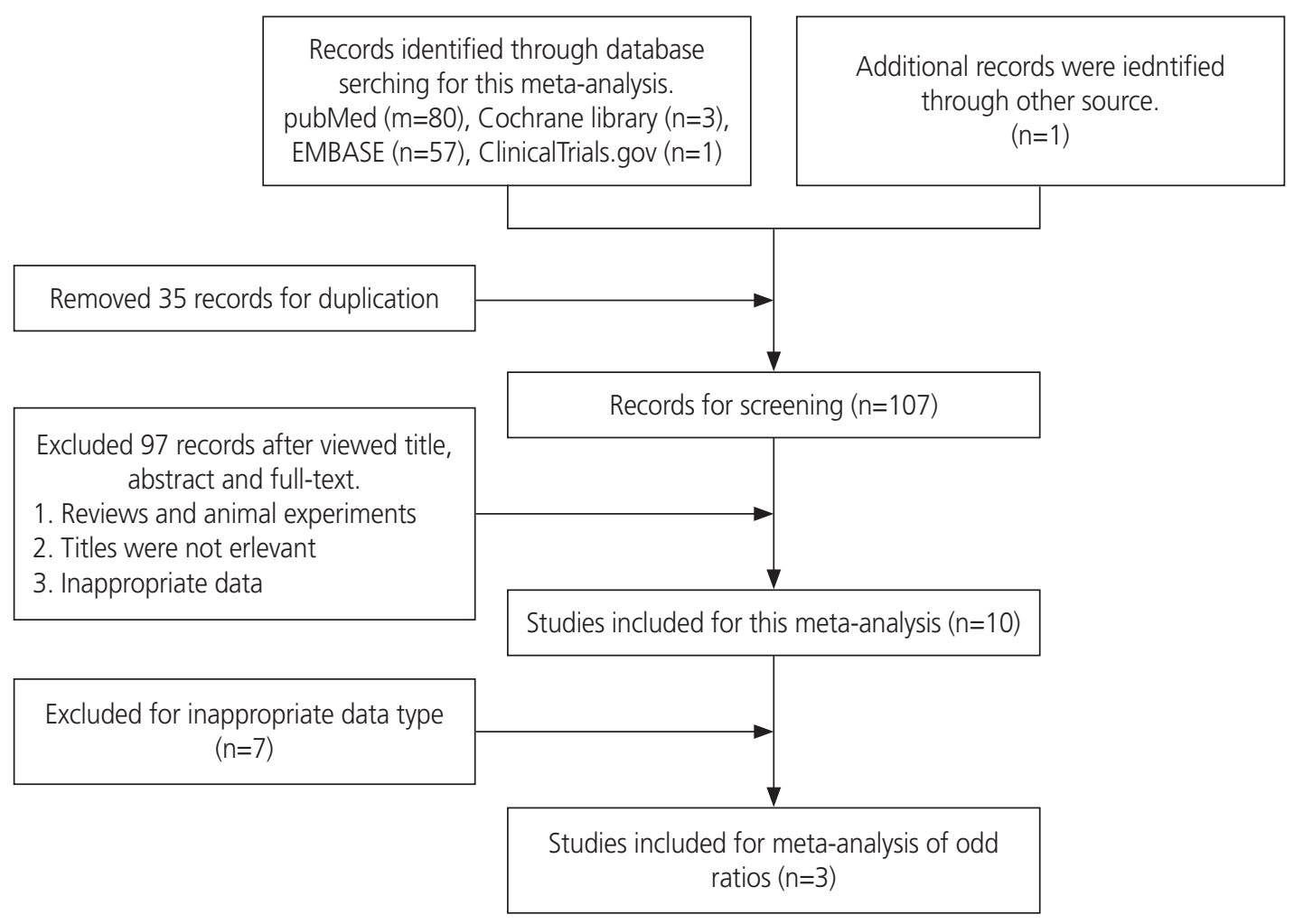

Fig. 1. Database flow chart for meta-analysis. 


\section{Obstetrics \& Gynecology Science}

Vol. 64, No. 4, 2021

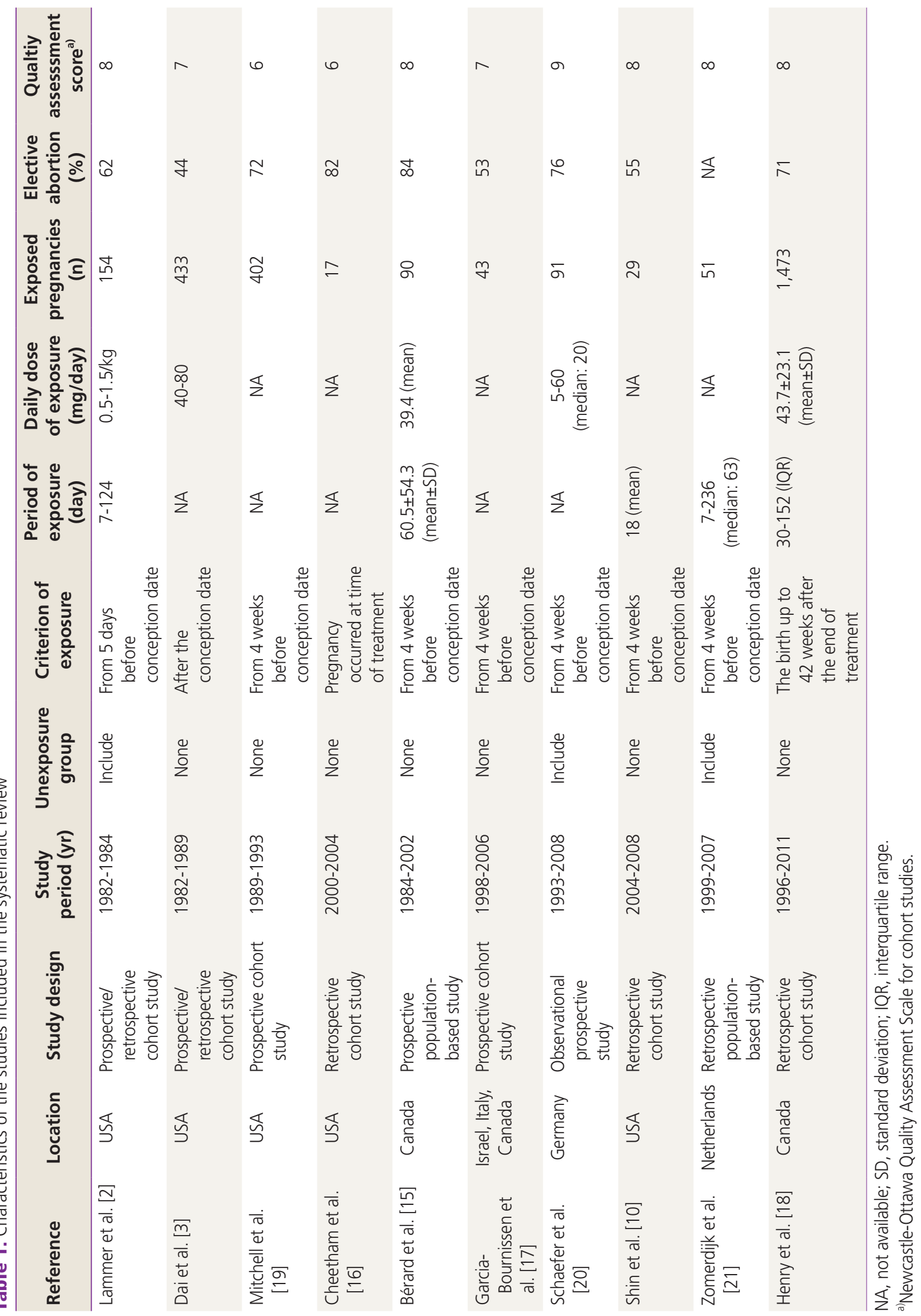




\section{Obstetrics \& Gynecology Science}

Eun Jeong Choi, et al. Isotretinoin malformations: meta-analysis

\section{Data extraction and quality assessment}

All extracted data were double-checked, and discrepancies were resolved by discussion. The following information was extracted from the included studies if available: the first author's name, year of publication, study design, location, assessment criteria of isotretinoin exposure, information on isotretinoin exposure (dosage, period, exposure timing); pregnancy outcomes; birth outcomes; congenital malformation; and the assessment criteria for MM and rate of congenital malformations among the unexposed control group. MM was defined as a physical or anatomical abnormality detected at birth and classified according to the categories listed in UpToDate [12].

Two independent authors (H.S.K and J.Y.H) assessed the quality of each included study using the Newcastle-Ottawa Scale (NOS) system [13]. A "star system" of NOS has been developed in which a study is judged on three broad perspectives: the selection of the study groups (four stars); the comparability of the groups (two stars); and the ascertain- ment of either the exposure or outcome of interest (three stars) for case-control or cohort studies respectively. Each criterion scores 1 star, except comparability, which scores up to two stars. The maximum NOS scores were 9 .

\section{Statistical analysis}

MM rates among the isotretinoin-exposed pregnant women were adjusted for sample size as extracted from the articles to calculate proportions and 95\% confidence intervals (95\% Cls) using meta-analysis of single proportions. This analysis aimed to calculate the overall proportion of studies reporting only isotretinoin, regardless of the comparison group.

We used a random-effects model (DerSimonian and Laird method with Mantel-Haenszel procedure) to assess the differences in MM rate between pregnant women unexposed and isotretinoin-exposed pregnant women and calculated the pooled OR and $95 \% \mathrm{Cl}$. The Cochrane Q test and $\mathrm{I}^{2}$ statistic were used to examine the heterogeneity. Heterogeneity was quantified as low with $\mathrm{I}^{2}<25 \%$, moderate with $\mathrm{I}^{2} \geq 25 \%$

Table 2. Pregnancy outcome and birth outcomes of studies included in the systematic review

\begin{tabular}{|c|c|c|c|c|c|c|c|c|}
\hline Reference & $\begin{array}{l}\text { Exposed } \\
\text { preg- } \\
\text { nancies }\end{array}$ & $\begin{array}{l}\text { Sponta- } \\
\text { neous } \\
\text { abortion }\end{array}$ & IUFD $^{a)}$ & $\begin{array}{l}\text { Total } \\
\text { birth }\end{array}$ & $\begin{array}{l}\text { Nor- } \\
\text { mal } \\
\text { birth }\end{array}$ & $\begin{array}{l}\text { Congenital } \\
\text { malforma- } \\
\text { tions }^{\text {b) }}\end{array}$ & $\begin{array}{c}\text { Major } \\
\text { congenital } \\
\text { malforma- } \\
\text { tions }\end{array}$ & $\begin{array}{l}\text { Outcome of major } \\
\text { malformation }\end{array}$ \\
\hline Lammer et al. [2] & 154 & $12(7.8)$ & 12 & 35 & 26 & 9 & 9 & $\begin{array}{l}\text { Cranium and face, heart, } \\
\text { thymus, CNS, combination }\end{array}$ \\
\hline Dai et al. [3] & 433 & $21(4.8)$ & 0 & 94 & 61 & 33 & 26 & $\begin{array}{l}\text { Cardiovascular, craniofacial, } \\
\text { CNS }\end{array}$ \\
\hline Mitchell et al. [19] & 402 & $76(18.9)^{c)}$ & 1 & 32 & 25 & 7 & 6 & $\begin{array}{l}\text { Ear, eye craniofacial, brain, } \\
\text { hypoplastic scrotum, } \\
\text { confluent eyebrows }\end{array}$ \\
\hline Cheetham et al. [16] & 17 & $2(11.8)$ & 0 & 1 & 1 & 0 & 0 & NA \\
\hline Bérard et al. [15] & 90 & $3(3.3)$ & 2 & 9 & 6 & 3 & 1 & $\begin{array}{l}\text { Congenital anomaly of face } \\
\text { and neck diagnosed at } \\
3 \text { years old }\end{array}$ \\
\hline $\begin{array}{l}\text { Garcia-Bournissen et al. } \\
\text { [17] }\end{array}$ & 43 & $1(2.3)$ & 0 & 14 & 12 & NA & 2 & Anotia, heart malformation \\
\hline Schaefer et al. [20] & 91 & $5(5.5)$ & 0 & 18 & $15^{\mathrm{d})}$ & 3 & 1 & Ventricular septal defect \\
\hline Shin et al. [10] & 29 & $3(10.3)$ & 0 & 9 & 8 & 1 & 1 & Polydactyly of fingers \\
\hline Zomerdijk et al. [21] & 51 & NA & 3 & 50 & $48^{d)}$ & 2 & 2 & $\begin{array}{l}\text { Neural tube defect, major } \\
\text { congenital anomaly not } \\
\text { further specified }\end{array}$ \\
\hline Henry et al. [18] & 1,473 & $290(19.7)$ & 0 & 118 & 107 & 11 & 11 & NA \\
\hline
\end{tabular}

Values are presented as number (\%).

IUFD, intrauterine fetal death; CNS, central nervous system; NA, not available.

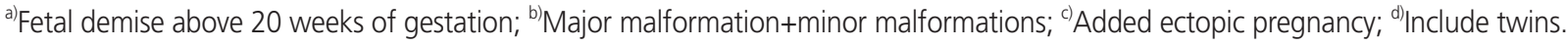




\section{Obstetrics \& Gynecology Science}

Vol. 64, No. 4, 2021

and $\leq 75 \%$, and high with $\mathrm{I}^{2}>75 \%$. We also performed subgroup analyses according to studies published before and after 2006. The meta-analyses were performed using the "meta" package of the R software (v. 3.5.1, R Foundation for Statistical Computing, Vienna, Austria) and Review Manager v5.3 (http://ims.cochrane.org/revman).

\section{Results}

\section{Study characteristics}

The search identified 142 articles, of which 35 duplicates were removed. After screening the titles and abstracts, 107 full-text articles were assessed, with an additional study located in the cited articles. Overall, 97 patients did not meet the selection criteria (Fig. 1). The characteristics of the 10 included studies are presented in Table 1. We performed a quality assessment of the 10 included studies using the NOS system, which is suitable for case-control studies (Table 1). The NOS scores ranged from 6 to 9 (mean=7.6). All of them were assigned an NOS score of 6 or above and were not judged to be at high risk of bias (score <4) [14].

Table 3. Characteristics of studies included in the meta-analysis

\begin{tabular}{|c|c|c|c|c|c|c|c|c|}
\hline \multirow[b]{2}{*}{ Reference } & \multicolumn{2}{|c|}{$\begin{array}{l}\text { Isotretinoin-unexposed } \\
\text { pregnanies }\end{array}$} & \multicolumn{6}{|c|}{ Isotretinoin-exposed pregnanies } \\
\hline & $\begin{array}{l}\text { Total preg- } \\
\text { nancies }\end{array}$ & $\begin{array}{l}\text { Major con- } \\
\text { genital mal- } \\
\text { formation }\end{array}$ & $\begin{array}{l}\text { Total } \\
\text { preg- } \\
\text { nancies }\end{array}$ & $\begin{array}{l}\text { Abor- } \\
\text { tion }^{\text {a) }}\end{array}$ & IUFD $^{b)}$ & $\begin{array}{l}\text { Normal } \\
\text { birth }\end{array}$ & $\begin{array}{l}\text { Congenital } \\
\text { malforma- } \\
\text { tions }^{c)}\end{array}$ & $\begin{array}{l}\text { Major congenital mal- } \\
\text { formations }\end{array}$ \\
\hline $\begin{array}{l}\text { Lammer et al. } \\
\text { [2] }\end{array}$ & 27,866 & $194(0.7)$ & 154 & 107 & 12 & 26 & 9 & $\begin{array}{c}9 \\
\text { (cranium and face, } \\
\text { heart, thymus, CNS, } \\
\text { combination) }\end{array}$ \\
\hline $\begin{array}{l}\text { Schaefer et al. } \\
\text { [20] }\end{array}$ & 329 & $12(3.6)$ & 91 & 74 & 0 & $15^{d)}$ & 3 & $\begin{array}{c}1 \\
\text { (ventricular septal defect) }\end{array}$ \\
\hline $\begin{array}{l}\text { Zomerdijk et al. } \\
\text { [21] }\end{array}$ & 208,108 & $9,041(4.3)$ & 51 & 0 & 3 & $48^{d)}$ & 2 & $\begin{array}{l}2 \\
\text { (neural tube defect, major } \\
\text { congenital anomaly not } \\
\text { further specified) }\end{array}$ \\
\hline
\end{tabular}

IUFD, intrauterine fetal death; CNS, central nervous system.

${ }^{\text {a) }}$ Elective abortion+spontaneous abortion; ${ }^{\text {b) }}$ Fetal demise above 20 weeks of gestation; 'Major malformation+minor malformations; ${ }^{d}$ Include twins.

\section{Study}

Lammer E.J., et al. 1985

Dai W.S., et al. 1992

Mitchell A.A., et al. 1995

Cheetham T.C., et al. 2006

Berard A., et al. 2007

F. garcia-Bournissen et al. 2008

Schaefer C. et al. 2010

Shin J., et al. 2011

Zomerdijk I.M., et al. 2014

Henry D., et al. 2016

$\begin{array}{ccr}\text { Events } & \text { Total } & \text { Weight } \\ 9 & 35 & 15.4 \% \\ 26 & 94 & 19.3 \% \\ 6 & 32 & 13.8 \% \\ 0 & 1 & 2.4 \% \\ 1 & 9 & 5.0 \% \\ 2 & 14 & 8.0 \% \\ 1 & 18 & 5.3 \% \\ 1 & 9 & 5.0 \% \\ 2 & 50 & 8.6 \% \\ 11 & 118 & 17.2 \% \\ & & \end{array}$

Total $(95 \% \mathrm{Cl})$

Heterogeneity: $\operatorname{Tau}^{2}=0.32 ; C h i^{2}=20.63, \mathrm{df}=9(P=0.01): I^{2}=56 \%$
IV, Random, 95\% CI

$0.26[0.12,0.43]$

$0.28[0.19,0.39]$

$0.19[0.07,0.36]$

$0.00[0.00,0.98]$

$0.11[0.00,0.48]$

$0.14[0.02,0.43]$

$0.06[0.00,0.27]$

$0.11[0.00,0.48]$

$0.04[0.00,0.14]$

$0.09[0.05,0.16]$

$0.15[0.09,0.23]$

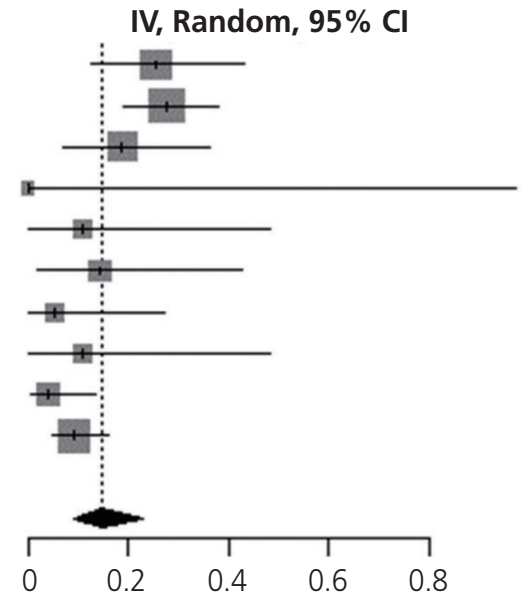

Fig. 2. Random-effect single-arm meta-analysis of major malformation prevalence in isotretinoin exposure of the 10 included studies. $\mathrm{Cl}$, confidence interval. 


\section{Obstetrics \& Gynecology Science}

Eun Jeong Choi, et al. Isotretinoin malformations: meta-analysis

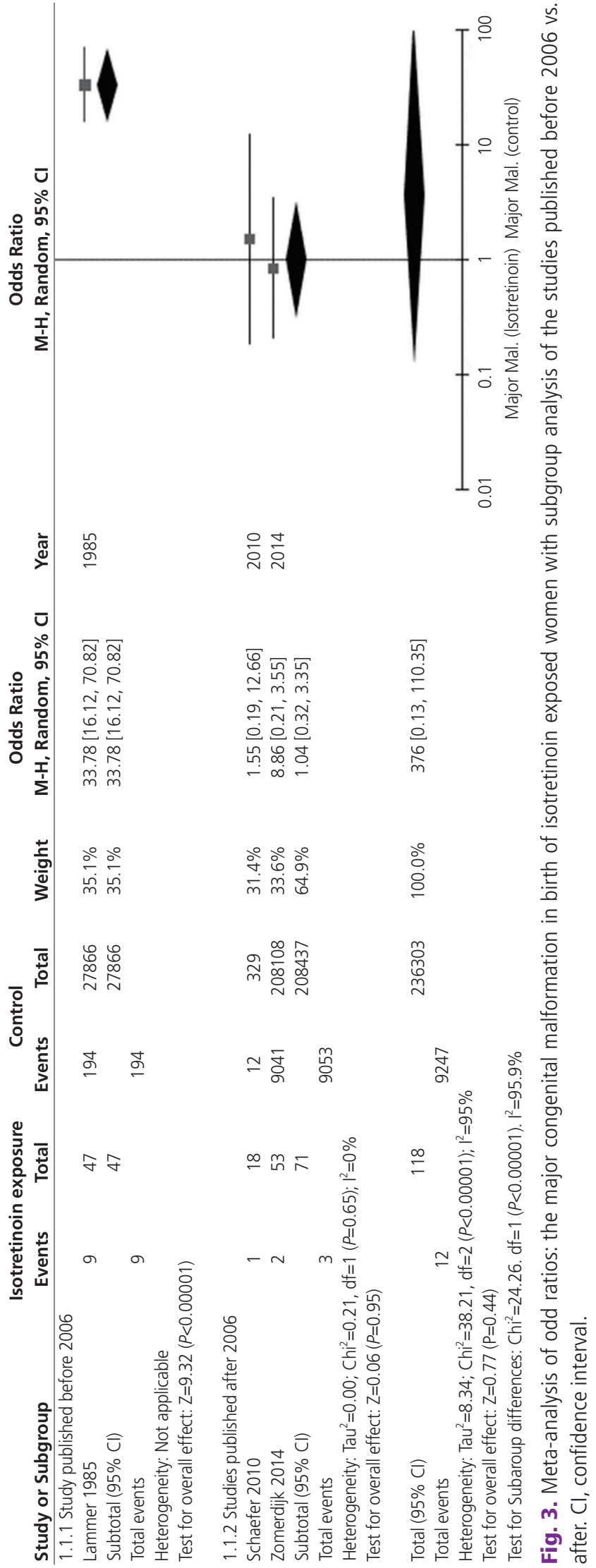

\section{Systematic review}

Ten studies were finally included in the meta-analysis $[2,3,10,15-21]$. For the pairwise meta-analysis, seven studies were excluded because of the absence of a comparison group. Three studies were included in the meta-analysis $[2,20,21]$.

The 10 studies included in the single-arm analysis included 2,783 participants exposed to isotretinoin during the periconception and pregnancy periods. The abortion rate among the isotretinoin-exposed pregnant women was $80 \%$, and $65 \%$ of them were confirmed to have elective abortion. There were 380 total births, with normal births without MM at 309. Additional data on the malformations and pregnancy outcomes are presented in Tables 2 and 3.

\section{MM rates among isotretinoin-exposed pregnant women}

First, a random-effect single-arm meta-analysis was performed in 11 studies using the MM rates of isotretinoinexposed pregnant women. MM was confirmed in 59 of the 380 births, and the pooled MM rate was 15\% (95\% $\mathrm{Cl}, 9-23 \%)$ (Fig. 2). Significant heterogeneity was detected $\left(I^{2}=56 \%, P=0.01\right)$ because of lower MM rates in published studies from 2006.

Subsequently, a random-effect pair-wise meta-analysis was performed on three studies comparing the MM assessment of isotretinoin-exposed groups versus the unexposed group. In the unexposed group, MM was confirmed in 9,247 of 236,302 births (3.9\%). In the isotretinoin-exposed group, MM was confirmed in 12 of the 118 births, with a pooled overall OR of $3.76(95 \% \mathrm{Cl}, 0.13-110.35)$ (Fig. 3). Significant heterogeneity was found $\left(I^{2}=95 \%, P<0.001\right)$ due to a study published before 2006, where the MM rate was higher than that after 2006. After 2006, the analysis demonstrated no significant heterogeneity $\left({ }^{2}=0 \%, P=0.65\right)$. The test for subgroup differences was significant $\left(I^{2}=95.9 \%, P<0.001\right)$. After 2006, the pooled OR of MM for isotretinoin exposure was significantly lower at $1.04\left(95 \% \mathrm{Cl}, 0.32-3.35 ; \mathrm{I}^{2}=0 \%\right)$.

\section{Discussion}

The rate of elective abortion in isotretinoin-exposed pregnancies has not declined until recently. Fig. 4 shows the rate of elective abortion in isotretinoin-exposed pregnancies ac- 


\section{Obstetrics \& Gynecology Science}

Vol. 64, No. 4, 2021

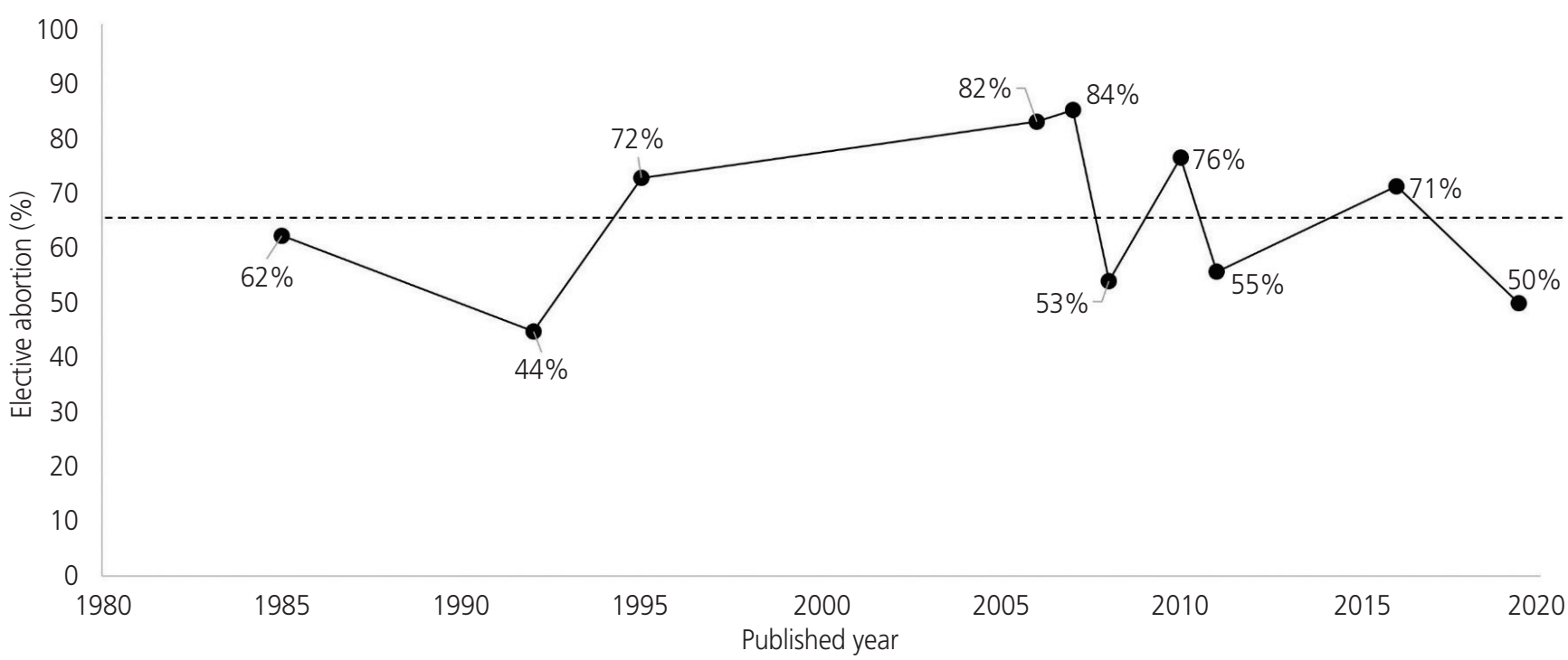

Fig. 4. The rate of elective abortion in isotretinoin-exposed pregnancy as per published studies (Lammer et al. [3], Dai et al. [4], Mitchell et al. [19], Cheetham et al. [16], Bérard et al. [15], Garcia-Bournissen et al. [17], Schaefer et al. [20], Shin et al. [10], Henry et al. [18], and MacDonald et al. [22]). The average rate of elective abortion was $42 \%$ during 4 weeks before conception and $57 \%$ during pregnancy.

cording to published studies. The average rate of elective abortion was $65 \%$ (range, 44-84\%). MacDonald et al. [22] reported an elective termination rate of $28 \%$. They reported that the rate of elective termination was lower than that reported in other studies. MacDonald et al. [22] calculated this rate based on the exposure criteria of 90 days before the last menstrual period (LMP) to the end of pregnancy. The rate of elective abortion was $42 \%$ during 30 days before LMP and $57 \%$ from LMP to LMP+30 days. This study was not accepted as a systematic review because it excluded data on malformation (number of babies, malformation description). The rates of elective abortion varied depending on the timing of isotretinoin exposure. Following exposure to isotretinoin, the rate of elective abortion during pregnancy was similar to that of elective abortion during the 30 days before LMP. The elective abortion rate is approximately $20 \%$ during the timeframe ranging from 90 days before LMP to 31 days before LMP [22]. The iPLEDGE program was implemented in 2006 to reduce fetal exposure to isotretinoin. Although the number of pregnancy-related adverse events in patients taking isotretinoin has decreased since 2006, pregnancy, abortion, and fetal defects associated with isotretinoin exposure continue to be a problem [23]. In Korea, the incidence of isotretinoin exposure is approximately 3 pregnancies per 10,000 births [24]. A risk management program (RMP) of isotretinoin as a pregnancy prevention program was launched in June
2019. However, the compliance of the RMP was not or much less effective than the iPLEDGE program.

In the included studies, the NOS scores ranged from 6 to 9 and were judged to be at a low risk of bias [14]. According to our systematic review and meta-analysis, the rate of MM in studies weighted for sample size in pregnant women exposed to isotretinoin is $15 \%$. In the three studies with both exposed and unexposed groups, the ORs of MM were 3.76. Importantly, after 2006, the ORs of MM for isotretinoin exposure were substantially lower at 1.04. These figures are different from those published and advertised after the first studies showing a malformation rate of up to $30 \%$ to $1 \%$ $[2,3,21]$. This huge variability in the rate of MM has caused confusion for the exposed pregnant women, their families, and medical providers. In our experience in counseling, we had no choice but to quote a higher figure of up to $30 \%$ risk. Pregnant women may have misperception or excessive fear due to this information and are likely to choose to terminate pregnancy. In Canada between 1984 and 2002, 90 of 8,609 women aged $13-45$ years who took isotretinoin became pregnant, and 76 (84\%) of them chose to terminate their pregnancy [15]. Similarly, in the United States, $72 \%$ of women who became pregnant while taking isotretinoin terminated their pregnancy [19].

In the present study, the rate of MM (15\%) is based on larger sample sizes and is statistically more powerful than the 


\section{Obstetrics \& Gynecology Science}

Eun Jeong Choi, et al. Isotretinoin malformations: meta-analysis

initial estimates. In other words, $85 \%$ of fetuses exposed in utero to isotretinoin are likely to be delivered without MM.

Our study clearly shows that there is a difference in ORs before and after 2006. The OR, 1.04, after 2006 was much lower than that of all studies lumped together (3.76). This difference may be explained by current smaller doses and possibly shorter duration of isotretinoin exposure during pregnancy. In terms of exposure dose, the highest dose was up to $87.3 \mathrm{mg} /$ day before 2006 and only $43.7 \mathrm{mg}$ after 2006. Regarding the duration of isotretinoin exposure during pregnancy, the last dose before 2006 was up to 10 weeks after conception, compared to 30 days of gestation after 2006. However, as a word of caution, the reported exposure dose and length have not been clearly reported based on their description in many of the included articles.

However, recently, there has been a tendency to reduce the dose and duration of isotretinoin regimen for acne treatment. The efficacy of isotretinoin at $0.5-1.0 \mathrm{mg} / \mathrm{kg}$ per day in the treatment of acne is well established in 1980 for the first time [25]. Since then, many other studies have confirmed its efficacy in a low-dose isotretinoin dose of $0.5-1.0 \mathrm{mg} / \mathrm{kg}$ per day [26-28]. The significant improvement in the administration of low-dose isotretinoin $(0.25-0.5 \mathrm{mg} / \mathrm{kg} /$ day for 3-6 months) in acne vulgaris was seen between $81 \%$ and $100 \%$ of varying duration. Due to the fewer side effects and greater patient satisfaction, low-dose isotretinoin can be considered in the treatment of moderate-to-severe acne [29]. In addition, isotretinoin therapy was associated with changes in plasma levels of homocysteine and folic acid in patients with acne. Patients treated with a higher cumulative dose of isotretinoin had markedly high homocysteine and low folic acid levels [30]. Kriangkrai et al. [31] suggested that folic acid reduced the teratogenic effects of isotretinoin-induced cellular damage in developing midfacial processes in rat embryos [31]. Folic acid is known to play an integral role in embryonic development.

To our knowledge, this study is the first systematic review and meta-analysis to describe the changing rate of reported MM after in utero isotretinoin exposure. The larger sample size in the study articles makes the results of this metaanalysis more stable and reliable. The rate of MM can help us provide more accurate information on pregnant women exposed to isotretnoin. In addition, the study indicates that further research is required on the dose and time response of isotretinoin.
There are several limitations to our study that need to be acknowledged. First, our meta-analysis included only three studies that compared the rates of MM in exposed and unexposed groups, and these studies were performed in different countries. Second, the limited sample sizes and inconsistent characteristics of the included articles prevented us from further analyzing the teratogenic risk in the subgroup analysis according to dose or gestation time and categorization of $\mathrm{MM}$ in the included studies. Third, there were numerous abortions of pregnancy and loss to follow-up, which may have underestimated the MM rates. Fourth, the quality assessment of the selected studies suggested that not all the studies were of high quality, which may have affected the accuracy of the results. Finally, we only evaluated MM as a fetal outcome. We could not evaluate long-term neurological impairment that might be much more concerning for parents and medical providers. While more long-term studies should be performed in the future, the present study suggests that the fetal risk of $\mathrm{MM}$ after in utero isotretinoin exposure may be lower than originally reported, changing the information that should be provided to expecting parents.

\section{Conflict of interest}

The authors declare no conflict of interest. The authors alone are responsible for the content and writing of this paper.

\section{Ethical approval}

No institutional approval was required because this was an analysis of publicly available data.

\section{Patient consent}

Informed consent was not required because this was an analysis of publicly available data.

\section{Funding information}

None. 


\section{Obstetrics \& Gynecology Science}

Vol. 64, No. 4, 2021

\section{References}

1. Layton A. The use of isotretinoin in acne. Dermatoendocrinol 2009;1:162-9.

2. Lammer EJ, Chen DT, Hoar RM, Agnish ND, Benke PJ, Braun JT, et al. Retinoic acid embryopathy. N Engl J Med 1985;313:837-41.

3. Dai WS, LaBraico JM, Stern RS. Epidemiology of isotretinoin exposure during pregnancy. J Am Acad Dermatol 1992;26:599-606.

4. Davis WL, Jacoby BH, Farmer GR, Cooper OJ. Changes in cytosolic calcium, bleb formation, and cell death in neural crest cells treated with isotretinoin and 4-oxoisotretinoin. J Craniofac Genet Dev Biol 1992;11:105-18.

5. United Kingdom Teratology Information Service (UKTIS). Use of isotretinoin in pregnancy [Internet]. London (UK): UKTIS; c2018 [cited 2020 Nov 20]. Available from: http://www.uktis.org./index.html.

6. Nulman I, Berkovitch M, Klein J, Pastuszak A, Lester RS, Shear $\mathrm{N}$, et al. Steady-state pharmacokinetics of isotretinoin and its 4-oxo metabolite: implications for fetal safety. J Clin Pharmacol 1998;38:926-30.

7. Rademaker M. Isotretinoin: dose, duration and relapse. What does 30 years of usage tell us? Australas I Dermatol 2013;54:157-62.

8. Torzecka JD, Dziankowska-Bartkowiak B, Gerlicz-Kowalczuk Z, Wozniacka A. The use of isotretinoin in low doses and unconventional treatment regimens in different types of acne: a literature review. Postepy Dermatol Alergol 2017;34:1-5.

9. Crijns I, Straus S, Luteijn M, Gispen-de Wied C, Raine J, de Jong-van den Berg L. Implementation of the harmonized EU isotretinoin pregnancy prevention programme: a questionnaire survey among European regulatory agencies. Drug Saf 2012;35:27-32.

10. Shin J, Cheetham TC, Wong L, Niu F, Kass E, Yoshinaga MA, et al. The impact of the iPLEDGE program on isotretinoin fetal exposure in an integrated health care system. J Am Acad Dermatol 2011;65:1117-25.

11. Teichert M, Visser LE, Dufour M, Rodenburg E, Straus SM, De Smet PA, et al. Isotretinoin use and compliance with the Dutch pregnancy prevention programme: a retrospective cohort study in females of reproductive age using pharmacy dispensing data. Drug Saf 2010;33:31526.
12. Bacino CA, Firth HV, Wilkins-Haug L, TePas E. Birth defects: epidemiology, types, and patterns [Internet]. Waltham (MA): UpToDate; c2017 [cited 2020 Nov 20]. Available from: https://www.uptodate.com/contents/ birth-defects-epidemiology-types-and-patterns.

13. Wells GA, Shea B, O'Connell D, Peterson J, Welch V, Losos M, et al. The Newcastle-Ottawa Scale (NOS) for assessing the quality of nonrandomised studies in metaanalyses [Internet]. Ottawa (CA): Ottawa Hospital Research Institute; c2011 [cited 2020 Nov 20]. Available from: http://www.ohri.ca/programs/clinical_epidemiology/oxford.asp.

14. Heneghan C, Aronson JK, Spencer E, Holman B, Mahtani $K R$, Perera $R$, et al. Oral hormone pregnancy tests and the risks of congenital malformations: a systematic review and meta-analysis. F1000Res 2018;7:1725.

15. Bérard A, Azoulay L, Koren G, Blais L, Perreault S, Oraichi D. Isotretinoin, pregnancies, abortions and birth defects: a population-based perspective. Br J Clin Pharmacol 2007;63:196-205.

16. Cheetham TC, Wagner RA, Chiu G, Day JM, Yoshinaga MA, Wong L. A risk management program aimed at preventing fetal exposure to isotretinoin: retrospective cohort study. J Am Acad Dermatol 2006;55:442-8.

17. Garcia-Bournissen F, Tsur L, Goldstein LH, Staroselsky A, Avner $\mathrm{M}$, Asrar $\mathrm{F}$, et al. Fetal exposure to isotretinoin-an international problem. Reprod Toxicol 2008;25:124-8.

18. Henry D, Dormuth C, Winquist B, Carney G, Bugden $S$, Teare $G$, et al. Occurrence of pregnancy and pregnancy outcomes during isotretinoin therapy. CMAJ 2016;188:723-30.

19. Mitchell AA, Van Bennekom CM, Louik C. A pregnancyprevention program in women of childbearing age receiving isotretinoin. N Engl J Med 1995;333:101-6.

20. Schaefer C, Meister R, Weber-Schoendorfer C. Isotretinoin exposure and pregnancy outcome: an observational study of the Berlin institute for clinical teratology and drug risk assessment in pregnancy. Arch Gynecol Obstet 2010;281:221-7.

21. Zomerdijk IM, Ruiter R, Houweling LM, Herings RM, Sturkenboom MC, Straus SM, et al. Isotretinoin exposure during pregnancy: a population-based study in The Netherlands. BMJ Open 2014;4:e005602.

22. MacDonald SC, Cohen JM, Panchaud A, McElrath TF, Huybrechts KF, Hernández-Díaz S. Identifying pregnan- 


\section{Obstetrics \& Gynecology Science}

Eun Jeong Choi, et al. Isotretinoin malformations: meta-analysis

cies in insurance claims data: methods and application to retinoid teratogenic surveillance. Pharmacoepidemiol Drug Saf 2019;28:1211-21.

23. Tkachenko E, Singer S, Sharma P, Barbieri J, Mostaghimi A. US Food and Drug Administration reports of pregnancy and pregnancy-related adverse events associated with isotretinoin. JAMA Dermatol 2019;155:1175-9.

24. Kim NR, Yoon SR, Choi JS, Ahn HK, Lee SY, Hong DS, et al. Isotretinoin exposure in pregnant women in Korea. Obstet Gynecol Sci 2108;61:649-54.

25. Layton AM, Cunliffe WJ. Guidelines for optimal use of isotretinoin in acne. J Am Acad Dermatol 1992;27(6 Pt 2):S2-7.

26. Amichai B, Shemer A, Grunwald MH. Low-dose isotretinoin in the treatment of acne vulgaris. J Am Acad Dermatol 2006;54:644-6.

27. Hermes B, Praetel C, Henz BM. Medium dose isotreti- noin for the treatment of acne. J Eur Acad Dermatol Venereol 1998;11:117-21.

28. Seukeran DC, Cunliffe WJ. Acne vulgaris in the elderly: the response to low-dose isotretinoin. $\mathrm{Br} J$ Dermatol 1998;139:99-101.

29. Abdelmaksoud A, Vojvodic A, Ayhan E, Dönmezdil $S$, Jovicevic TV, Vojvodic $P$, et al. Depression, isotretinoin, and folic acid: a practical review. Dermatol Ther 2019;32:e13104.

30. Kim HJ, Lee SM, Lee JS, Lee SY, Chung EH, Cho MK, et al. Homocysteine, folic acid, and vitamin B12 levels in patients on isotretinoin therapy for acne vulgaris: a meta-analysis. J Cosmet Dermatol 2020;19:736-45.

31. Kriangkrai R, Chareonvit S, Iseki S, Limwongse V. Pretreatment effect of folic acid on 13-cis-RA-induced cellular damage of developing midfacial processes in cultured rat embryos. Open Dent J 2017;11:200-12. 